\title{
PEMIMPIN PROFESIONAL MADRASAH
}

\section{ABDILLAH MUNDIR \\ Fakultas Agama Islam Universitas Yudharta Pasuruan abdiloveu@gmail.com}

\begin{abstract}
Abtract
Professional leaders madrasah education institutions is a capable of giving direction, setting objectives to be achieved, providing a solution for any problems, make decisions, site planning and strategy. He was a terrific in implementing the concept. He actively communicate, coordinate, supervise and conduct the evaluation. The important thing is he motivate teachers and staff to becomeprofessional teachers and professional staff. He built the morale and spirit of togetherness in madrasa education institutions, teach, train, and give advice. All hope it will materialize when a headmaster has the integrity to lead madrasah education institution to become an institution of superior quality
\end{abstract}

\begin{abstract}
Abstrak
Pemimpin profesional lembaga pendidikan madrasah adalah seorang yang mampu memberikan arah, menetapkan tujuan yang akan dicapai, memberikan solusi terhadap setiap permasalahan, membuat berbagai keputusan, perecanaan dan strategi. Ia adalah seorang yang hebat dalam pengimplementasian konsep. Ia aktif berkomunikasi, berkoordinasi, mensupervisi dan mengadakan evaluasi. Yang terpenting adalah ia memotivasi para guru dan tenaga kependidikan untuk menjadi guru dan tenaga kependidikan yang profesional. Ia membangun moral dan semangat kebersamaan dalam lembaga pendidikan madrasah, mengajarkan, melatih, dan memberi petuah. Semua harapan itu akan terwujud bila seorang kepala madrasah memiliki integritas untuk memimpin lembaga pendidikan madrasah menjadi lembaga yang unggul dan berkualitas.
\end{abstract}

\section{Kata Kunci : Pemimpin Profesional, Lembaga Pendidikan Madrasah}

\section{Pendahuluan}

Kepemimpinan merupakan Hal yang penting bagi suatu kelompok atau organisasi kelembagaan. Hal ini karena kepemimpinan merupakan salah satu faktor yang sangat mempengaruhi bagi keberhasilan kelompok tersebut untuk mencapai tujuan. Pemimpin adalah seseorang yang mempunyai kemampuan untuk mempengaruhi perilaku orang lain di dalam kerjanya dengan menggunakan kekuasaan. Kekuasaan adalah kemampuan untuk mengarahkan dan mempengaruhi bawahan sehubungan dengan tugas-tugas yang harus dilaksanakannya. ${ }^{1}$

\footnotetext{
${ }^{1}$ Nanang Fatah, Landasan Manajemen Pendidikan (Bandung: Remaja Rosda Karya, 1999), 19.
} 
Kepemimpinan dalam madrasah adalah segenap kegiatan dalam usaha mempengaruhi personal di lingkungan pendidikan pada situasi tertentu agar mereka melalui usaha kerja sama, mau bekerja dengan penuh tanggung jawab dan ikhlas demi tercapainya tujuan pendidikan yang telah ditetapkan. ${ }^{2}$ Ia memiliki peranan penting karena ia mempengaruhi, mengkoordinasi, membimbing, dan mengarahkan serta mengawasi semua personalia dalam hal yang ada kaitannya dengan kegiatan Pemimpin dalam dalam lembaga pendidikan madrasah yang dilaksanakan untuk mencapai tujuan pendidikan madrasah.

Ada beberapa pertimbangan yang penting bagi kepemimpinan kepala madrasah. Pertama, kepala madrasah harus mampu mengkomunikasikan nilainilai lembaga terhadap staf pengajar, pelajar, dan masyarakat luas. Kedua, kepala madrasah harus mampu memahami, berkomunikasi dan mendiskusikan proses yang berkembang dalam lembaga dengan tidak hanya duduk di belakang meja kerjanya. Ketiga, Ia harus mampu menumbuhkan rasa kebersamaan, keinginan, semangat dan potensi dari semua staf untuk mencapai tujuan. ${ }^{3}$

Kepemimpinan dalam lingkungan madrasah cenderung terletak pada kekuatan nilai-nilai (keagamaan) yang menjadi pusat perhatian kepala madrasah. Bahkan sering karena penekanan kepemimpinan yang menekankan aspek nilai, maka aspek teknis manajemen kurang begitu diperhatikan. Karena itu, isu-isu yang harus diperhatikan adalah masalah kepemimpinan, terutama bagaimana kualitas kepemimpinan dapat diidentifikasi dan dipelihara agar kekuatan kepemimpinan memiliki pondasi yang bersifat teknikal dan bersifat nilai yang dapat digerakkan. Dengan demikian kepala madrasah perlu memahami dan mengkritisi komponen-komponen yang perlu dipertimbangkan dalam pengembangan proses pembelajaran. ${ }^{4}$

Kepemimpinan kepala madrasah sebagai agen perubahan mempunyai peranan aktif dalam peningkatan mutu pendidikan, sehingga harus memiliki kemampuan sebagai leader. Kepemimpinan kepala madrasah yang baik adalah mampu mengelola semua sumber daya pendidikan untuk mencapai tujuan pendidikan baik dari sisi pembelajaran maupun pengembangan sumber daya manusia yang profesional bagi madrasah.

Kepala madrasah merupakan salah satu komponen pendidikan yang paling berperan dalam meningkatkan kualitas pendidikan. Ada hubungan erat antara mutu kepala madrasah dengan berbagai aspek kehidupan madrasah seperti disiplin, iklim budaya madrasah, dan perilaku peserta didik. Menyadari hal tersebut, kepala madrasah dihadapkan pada tataran untuk melaksanakan pendidikan secara terarah, berencana, dan berkesinambungan menetapkan

\footnotetext{
2 U. Husna Asmara, Pengantar Kepemimpinan Pendidikan (Bogor: Ghalia Indonesia, 1985), 118.

3 Syafaruddin, Manajemen Mutu Terpadu dalam Pendidikan, Konsep, Strategi, dan Aplikasi (Jakarta: PT. Gramedia Widiasarana Indonesia, 2002), 57.

${ }^{4}$ Muhaimin, Wacana Pengembangan Pendidikan Islam (Yogyakarta: Pusat Studi Agama, Politik dan Masyarakat (PSAPM) bekerjasama dengan Pustaka Pelajar, 2003), 185.
} 
kebijakan-kebijakan yang dianggap dapat meningkatkan kualitas pendidikan madrasah.

Kebijakan merupakan unsur vital bagi sebuah organisasi pendidikan madrasah. Ia adalah landasan dan garis dasar organisasi dalam menjalankan aktifitasnya guna mencapai tujuan. Kebijakan biasanya diwujudkan dalam bentuk putusan, strategi, rencana, peraturan, kesepakatan, konsensus, program dan sebagainya yang menjadi acuan organisasi dalam menjalankan aktivitas guna mencapai tujuan. ${ }^{5}$ Kepala madrasah dituntut memiliki keterampilan yang handal untuk membuat keputusan-keputusan yang dapat dijadikan dasar, strategi, atau program aktivitas sekolah. Kemampuan kepala sekolah dalam membuat keputusan-keputusan bermutu melalui langkah-langkah sistematis sangat menentukan efektiftas sekolah.

Kebijakan kepala madrasah akan mempengaruhi mekanisme kerja madrasah dan berperan besar dalam meningkatkan profesionalitas guru. Kebijakan yang dapat mendorong peningkatan profesionalitas guru akan sangat berpengaruh terhadap peningkatan mutu sekolah. Sebaliknya, bila kebijakan tidak dapat mendorong peningkatan, maka kebijakan tersebut akan berdampak pada penurunan mutu sekolah. Maka disini, secara tidak langsung kebijakan kebijakan sangat berperan dalam meningkatkan profesionalitas guru.

\section{Tugas Pokok Kepala Madrasah}

Tugas pokok kepala madrasah pada semua jenjang mencakup tiga bidang, yaitu: (1) tugas manajerial, (2) supervisi dan (3) kewirausahaan. Uraian tugas pokok tersebut adalah sebagai berikut: ${ }^{6}$

\section{Tugas Manajerial}

Tugas kepala madrasah dalam bidang manajerial berkaitan dengan pengelolaan sekolah, sehingga semua sumber daya dapat disediakan dan dimanfaat-kan secara optimal untuk mencapai tujuan sekolah secara efektif dan efisien.

Tugas manajerial ini meliputi (1) Menyusun perencanaan madrasah, (2) Mengelola program pembelajaran, (3) Mengelola kesiswaan, (4) Mengelola sarana dan prasarana, (5) Mengelola personal madrasah, (6) Mengelola keuangan madrasah, (7) Mengelola hubungan madrasah dan masyarakat, (8) Mengelola administrasi madrasah, (9) Mengelola sistem informasi madrasah, (10) Mengevaluasi program madrasah, dan (11) Memimpin madrasah

\section{Tugas Supervisi}

Selain tugas manajerial, kepala madrasah juga memiliki tugas pokok melakukan supervisi terhadap pelaksanaan kerja guru dan staf. Tujuannya adalah untuk menjamin agar guru dan staf bekerja dengan baik serta menjaga mutu proses maupun hasil pendidikan di madrasah. Dalam tugas supervisi ini tercakup kegiatan-kegiatan: (1) Merencanakan program supervisi, (2) Melaksanakan program supervisi, dan (3) Menindaklanjuti program supervisi

\footnotetext{
5 Syaiful Sagala, Administrasi Pendidikan Kontemporer (Bandung: Alfabeta, 2005), 130.

6, Dirjen Pendidikan Islam, Penilaian Kinerja Kepala Sekolah, (Kemenag RI, 2015), 18.
} 


\section{Tugas Kewirausahaan}

Di samping tugas manajerial dan supervisi, kepala madrasah juga memiliki tugas kewirausahaan. Tugas kewirausahaan ini tujuannya adalah agar madrasah memiliki sumber-sumber daya yang mampu mendukung jalannya madrasah, khususnya dari segi finansial. Selain itu juga agar madrasah membudayakan perilaku wirausaha di kalangan warga madrasah, khususnya para siswa.

\section{Kompetensi Kepribadian Kepala Madrasah}

Dasar kompetensi kepribadian ini akan sangat menentukan kompetensi lainnya, khususnya dalam melaksanakan program pendidikan nasional, propinsi, dan kabupaten/kota. Sebagai tambahan pengetahuan dan keilmuan dalam bidang perencanaan dan pelaksanaan program pendidikan, kepala madrasah harus mampu menunjukkan kinerjanya berdasarkan kebijakan, perencanaan, dan program pendidikan.

Untuk memiliki Kompetensi Kepribadian kepala madrasah harus memiliki kepribadian: (1) Berakhlak mulia dan menjadi teladan bagi komunitas madrasah; (2) Memiliki integritas kepribadian sebagai pemimpin; (3) Memiliki keinginan yang kuat dalam pengembangan diri; (4) Bersikap terbuka dalam melaksanakan tugas pokok dan fungsi; (5) Mengendalikan diri dalam menghadapi masalah; dan (6) Memiliki bakat dan minat jabatan sebagai pemimpin pendidikan madrasah ${ }^{7}$.

Berhubungan dengan kemampuannya sebagai pemimpin madrasah. Subkompetensi kepribadian ini dapat terwujud jika kepala madrasah memiliki pengetahuan dan keterampilan, di antaranya: (a) memahami teori-teori kepemimpinan, memilih strategi yang tepat untuk mencapai visi, misi, tujuan, dan sasaran madrasah; (b) memiliki power dan kesan positif untuk mempengaruhi bawahan dan orang lain; (c) memiliki kemampuan intelektual sebagai smart school principal agar mampu memobilisasi sumberdaya yang ada di lingkungannya; (d) mengambil keputusan secara cepat, tepat dan cekat; (e) mendorong perubahan melalui berbagai inovasi sekolah; (f) berkomunikasi secara lancar; (g) menggalang teamwork yang kompak, cerdas dan dinamis; (h) mendorong kegiatan yang bersifat kreatif; dan (i) menciptakan sekolah sebagai organisasi belajar yaitu sebagai learning organization.

Kepala madrasah harus mempunyai keinginan yang kuat dalam pengembangan diri sebagai kepala madrasah. Kepala madrasah tidak hanya dituntut untuk melakukan tugas-tugas di luar kebutuhan dirinya saja, tetapi ia perlu juga memiliki kemampuan dalam mengembangkan dirinya sendiri. Kompetensi ini bisa diwujudkan jika ia mampu untuk: (1) mengidentifikasi karakteristik kepala madrasah yang efektif; (2) mengembangkan kemampuan diri pada dimensi tugasnya; (3) mengembangkan dirinya pada dimensi proses pengambilan keputusan, pengkoordinasian, pemberdayaan, pemrograman, dan pengevaluasian; (4) mengembangkan dirinya pada dimensi lingkungan yaitu waktu, tempat, sumberdaya, dan kelompok kepentingan; (5) mengembangkan

\footnotetext{
7 Dirjen Peningkatan Mutu Tenaga Pendidik dan Tenaga Kependidikan, Penilaian Kinerja Kepala Sekolah, (Depdiknas, 2008), 10.
} 
keterampilan personal yang meliputi organisasi diri, hubungan antar manusia, pembawaan diri, pemecahan masalah, gaya bicara, dan gaya menulis. ${ }^{8}$

\section{Kompetensi Manajemerial Kepala Madrasah}

Kompetensi kepala madrasah lain yang harus dimiliki yaitu kompetensi kepala madrasah dalam memahami madrasah sebagai sistem yang harus dipimpin dan dikelola dengan baik, di antaranya adalah pengetahuan tentang manajemen. Dengan kemampuan dalam mengelola ini nantinya akan dijadikan sebagai pegangan cara berfikir, cara mengelola dan cara menganalisis sekolah dengan cara berpikir seorang manajer. Kepala smadrasah harus mampu menunjukkan perilakunya dan mampu untuk mengidentifikasi dan mengembangkan jenis-jenis input sekolah; mengembangkan proses belajar mengajar, pengkoordinasian, pengambilan keputusan, pem-berdayaan, pemotivasian, pemantauan, pensupervisian, dan pengevaluasian. Kepala sekolah harus mampu menunjukkan upaya dalam meningkatkan output sekolah yaitu kualitas, produktivitas, efisiensi, efektivitas, dan inovasi.

Bidang-bidang garapan manajerial seorang kepala madrasah adalah beberapa hal sebagai yaitu: (a) menyusun perencanaan madrasah mengenai berbagai tingkatan perencanaan; (b) mengembangkan organisasi madrasah sesuai dengan kebutuhan; (c) memimpin madrasah dalam rangka pendayagunaan sumber daya madrasah secara optimal; (d) mengelola perubahan dan pengembangan madrasah menuju organisasi pembelajar yang efektif; (e) menciptakan budaya dan iklim madrasah yang kondusif dan inovatif bagi pembelajaran pesertadidik; (f) mengelola guru dan staf dalam rangka pendayagunaan sumber daya manusia secara optimal; (g)mengelola sarana dan prasarana madrasah dalam rangka pendayagunaan secara optimal; (h)mengelola hubungan madrasah dan masyarakat dalam rangka pencarian dukungan ide, sumber belajar dan pembiyanaan madrasah; (i) mengelola peserta didik dalam rangka penerimaan peserta didik baru, dan penempatan serta pengembangan kapasitas peserta didik; $(j)$ mengelola pengembangan kurikulum dan kegiatan pembelajaran sesuai dengan arah dan tujuan pendidikan nasional; (k) mengelola keuangan madrasah sesuai dengan prinsip pengelolaan yang akuntabel, tranfaran dan efisien; (l) mengelola ketatausahaan madrasah dalam mendukung pencapaian tujuan madrasah; (m) mengelola unit layanan khusus madrasah dalam mendukung kegiatan pembelajaran dan kegiatan peserta didik di madrasah; (n) mengelola sistem informasi madrasah dalam mendukung penyusunan program dan pengambilan keputusan; (o)memanfaatkan kemajuan teknologi informasi bagi peningkatan pembelajaran dan manajemen madrasah; (p) melakukan monitoring, evaluasi, dan pelaporan pelaksanakan program kegiatan madrasah dengan prosedur yang tepat, serta merencanakan tindak lanjut.

Kemampuan yang mendukung subkompetensi mengelola ketatausahaan madrasah dalam mendukung pencapaian tujuan madrasah ini bisa diwujudkan

\footnotetext{
8 Dirjen Peningkatan Mutu Tenaga Pendidik dan Tenaga Kependidikan, Penilaian Kinerja Kepala Sekolah, (Depdiknas, 2008), 11.
} 
oleh seorang kepala madrasah secara utuh jika memperoleh dukungan dari sistem yang sudah ia kembangkan bersama dengan komponen madrasah lainnya. Dengan demikian pengawas sekolah bisa menilai kinerja ke-pala sekolah yaitu dengan melalui review dokumen termasuk sistem adminis-trasi sekolah. Pengawas sekolah juga bisa melakukannya dengan cara mela-kukan observasi terhadap kondisi lingkungan sekolah yang terlihat sebagai dampak dari strategi pengelolaan yang dikembangkan oleh kepala sekolah itu sendiri.

Sebagai manajer sekolah, kepala sekolah harus memahami kurikulum. Dengan demikian kepala madrasah dalam upaya mewujudkan kinerjanya dalam bidang ini, ia harus mampu untuk: (1) memfasilitasi madrasah untuk membentuk dan memberdayakan tim pengembang kurikulum; (2) memberdayakan tenaga kependidikan sekolah agar mampu menyediakan dokumen-dokumen kurikulum; (3) memfasilitasi guru untuk mengembangkan standar kompetensi setiap mata pelajaran; (4) memfasilitasi guru untuk menyusun silabus setiap mata pelajaran; (5) memfasilitasi guru untuk memilih buku sumber yang sesuai untuk setiap mata pelajaran; (6) mengarahkan tenaga kependidikan untuk menyusun rencana dan program pelaksanaan kurikulum; (7) membimbing guru dalam mengembangkan dan memperbaiki proses belajar mengajar; (8) mengarahkan tim pengembang kurikulum untuk mengupayakan kesesuaian kurikulum dengan kemajuan ilmu pengetahuan, teknologi, dan seni, tuntutan dan kebutuhan masyarakat, kebutuhan peserta didik; (9) menggali dan memobilisasi sumberdaya pendidikan; (10) mengidentifikasi kebutuhan bagi pengembangan kurikulum lokal; (11) mengevaluasi pelaksanaan kurikulum.

Kepala madrasah dalam memahami dan menghayati Standar Pelayanan Minimal, melaksanakan SPM secara tepat serta memahami lingkungan sekolah sebagai bagian dari sistem sekolah yang bersifat terbuka. Kinerja kepala sekolah lainnya antara lain mengelola guru dan staf dalam rangka pendayagunaan sumber daya manusia secara optimal. Hal ini dapat dilihat dari indikatorindikator yang mencakup: (1) mengidentifikasi karakteristik tenaga kependidikan yang efektif; (2) merencanakan tenaga kependidikan madrasay yaitu permintaan, persediaan, dan kesenjangan); (3) merekrut, menyeleksi, menempatkan, dan mengorientasikan tenaga kependidikan baru; (4) mengembangkan profesionalisme tenaga kependidikan; (5) memanfaatkan dan memelihara tenaga kependidikan; (6) menilai kinerja tenaga kependidikan; (7) mengembangkan sistem pengupahan, reward, dan punishment yang mampu menjamin kepastian dan keadilan; (8) melaksanakan dan mengembangkan sistem pembinaan karir; (9) memotivasi tenaga kependidikan; (10) membina hubungan kerja yang harmonis; (11) memelihara dokumentasi personel sekolah atau mengelola administrasi personel sekolah; (12) mengelola konflik; (13) melakukan analisis jabatan dan menyusun uraian jabatan tenaga kependidikan; dan (13) memiliki apresiasi, empati, dan simpati terhadap tenaga kependidikan.

Dalam hal kompetensi manajerial kepala madrasah dalam mengelola peserta didik, seorang kepala madrasah harus mampu menunjukkan kemampuan dalam: (1) mengelola penerimaan siswa baru, mengelola pengembangan bakat, minat, kreativitas dan kemampuan siswa; (2) mengelola sistem bimbingan dan 
konseling yang sistematis; (3) memelihara disiplin siswa; (4) menyusun tata tertib sekolah; (5) mengupayakan kesiapan belajar siswa baik fisik dan mental; (6) mengelola sistem pelaporan perkembangan siswa; dan (7) memberikan layanan penempatan siswa dan mengkoordinasikan studi lanjut.

Seiring dengan perkembangan Teknologi Informasi dan Komunikasi di lembaga pendidikan madrasah hendaknya mampu menyesuaikan diri, salah satunya akan tergantung kepada kepala madrasahnya, apakah ia mampu mengubah budaya madrasah, sesuai dengan kemajuan berpikirnya tentang bagaimana memanfaatkan Teknologi Informasi dan Komunikasi dalam mengelola sekolah. Dalam hal ini di antaranya dapat diwujudkan dalam bentuk upaya kepala madrasah melakukan aktivitas yang mencakup: (1) mengembangkan prosedur dan mekanisme layanan sistem informasi, serta sistem pelaporan; (2) mengembangkan pangkalan data sekolah yaitu data kesiswaan, keuangan, ketenagaan, dan fasilitas; (3) mengelola hasil pangkalan data sekolah untuk merencanakan program pengembangan madrasah; (4) menyiapkan pelaporan secara sistematis, realistis dan logis; dan (5) mengembangkan sim berbasis komputer.

Setelah kepala madrasah mampu untuk memanfaatkan Teknologi, maka bagaimana ia mampu juga dalam memanfaatkan informasinya untuk kepentingan manajemen sekolahnya. Untuk kepentingan menilai kinerja selanjutnya pengawas sekolah harus mampu melihat kemampuan kepala sekolah dalam hal melaksanakan subkompetensi mengelola sistem informasi madrasah dalam mendukung penyusunan program dan pengambilan keputusan, maka seorang kepala sekolah harus mampu menunjukkan unjuk kerjanya yaitu untuk mengambil keputusan secara terampil dapat dicapai melalui kemampuan untuk: (a) menjaring informasi berkualitas sebagai bahan untuk mengambil keputusan; (b) mengambil keputusan secara cepat, tepat, dan cekat; (c) memperhitungkan akibat pengambilan keputusan dengan penuh perhitungan yaitu least cost and most benefit; (d) menggunakan sistem informasi madrasah sebagai dasar dalam pengambilan keputusan. ${ }^{9}$

\section{Kompetensi Kewirausahaan Kepala Madrasah}

Kompetensi kepala madrasah yang cukup sentral dan merupakan pokok dari keberlanjutan program madrasah diantaranya adalah kompetensi Kewirausahaan. Sebagai salah satu cara bagaimana madrasah mampu mewujudkan kemampuan dalam wirausaha ini maka kepala madrasah harus mampu menunjukkan kemampuan dalam menjalin kemitraan dengan pengusaha atau donatur, serta mampu memandirikan sekolah dengan upaya berwirausaha. Secara rinci kemampuan atau kinerja kepala madrasah yang mendukung terhadap perwujudan kompetensi kewirausahaan ini, di antara mencakup: (a) menciptakan inovasi yang berguna bagi pengembangan sekolah/madrasah; (b) bekerja keras untuk mencapai keberhsilsan madrasah sebagai organisasi

\footnotetext{
${ }_{9}$ Dirjen Peningkatan Mutu Tenaga Pendidik dan Tenaga Kependidikan, Penilaian Kinerja Kepala Sekolah, (Depdiknas, 2008), 18.
} 
pembelajaran yang efektif; (c) memiliki motivasi yang kuat untuk sukses dalam me-laksanakan tugas pokok dan fungsinya sebagai pemimpin madrasah; (d) pantang menyerah dan selalu mencari solusi terbaik dalam menghadapi kendala yang dihadapi madrasah; (e) memiliki naluri kewirausahaan dalam mengelola kegiatan jasa madrasah sebagai sumber belajar peserta didik.

Kompetensi yang diasumsikan akan mampu memberikan kemajuan pesat di masa yang akan datang, yaitu kompetensi yang harus diwujudkan kepala madrasah pada aspek kreativitas, inovasi, dan kewirausahaan. Kompetensi ini dapat terwujud jika ia mampu untuk: (1) memahami dan menghayati arti dan tujuan inovasi sekolah; (2) menggunakan metode, teknik dan proses perubahan sekolah; (4) menumbuhkan iklim yang mendorong kebe-basan berfikir untuk menciptakan kreativitas dan inovasi; (5) mendorong warga sekolah untuk melakukan eksperimentasi, keberanian moral untuk melakukan hal-hal baru; (6) menghargai hasil-hasil kreativitas warga sekolah dengan memberikan rewards; dan (7) menumbuhkan jiwa kewirausahaan warga sekolah.

Kepala madrasah sebagai seorang wirausahawan yang sukses harus memiliki tiga kompetensi pokok yaitu pengetahuan, keterampilan, dan sikap kewirausahaan. Ketiga kompetensi tersebut saling berkaitan. Kompetensi merupakan penguasaan pengetahuan, keterampilan, dan sikap. Pengetahuan adalah kumpulan informasi yang disimpan di otak dan dapat dipanggil jika dibutuhkan. Keterampilan adalah kemampuan menerapkan pengetahuan. Sikap adalah sekumpulan kualitas karakter yang membentuk kepribadian seseorang. Seseorang yang tidak memiliki ketiga kompetensi tersebut akan gagal sebagai wirausahawan yang sukses.

Keterampilanyang dibutuhkan oleh seorang wirausahawan adalah keterampilan teknikal, manajemen bisnis, dan jiwa kewirausahaan personal. Keterampilan teknikal meliputi: mampu menulis, berbicara, mendengar, memantau lingkungan, teknik bisnis, teknologi, mengorganisasi, membangun jaringan, gaya manajemen, melatih, bekerja sama dalam kerja tim (teamwork). Manajemen bisnis meliputi: perencanaan bisnis dan menetapkan tujuan bisnis, pengambilan keputusan, hubungan manusiawi, pemasaran, keuangan, pembukuan, manajemen, negosiasi, dan mengelola perubahan. Jiwa wirausahawan personal meliputi: disiplin, berani mengambil risiko diperhitungkan, inovatif, berorientasi perubahan, kerja keras, pemimpin visioner, dan mampu mengelola perubahan..$^{10}$

\section{Kompetensi Supervisi Kepala Madrasah}

Secara bahasa supervisi berarti mengamati, mengawasi, atau membimbing kegiatan-kegiatan yang dilakukan oleh orang lain dengan maksud untuk mengadakan perbaikan. Supervisi berasal dari kata super artinya lebih atau atas, dan vision artinya melihat atau meninjau. Secara estimologis supervisi artinya melihat atau meninjau yang dilakukan oleh atasan terhadap pelaksanaan kegiatan

10 Bambang Wijanarko, Konsep Kewirausahaan Bagi Kepala Sekolah, (http://www.vedcmalang.com, 2015). 
bawahannya. ${ }^{11}$ supervisi adalah suatu aktivitas pembinaan yang direncanakan untuk membantu para guru dan pegawai sekolah lainnya dalam melakukan pekerjaan mereka secara efektif. ${ }^{12}$ Jadi supervisi adalah suatu usaha menstimulasi, mengkoordinasi dan membimbing secara kontinu pertumbuhan guru-guru di madrasah baik secara individual maupun secara kolektif, agar lebih mengerti dan lebih efektif dalam mewujudkan seluruh fungsi pengajaran. ${ }^{13}$

Seorang kepala madrasah yang berfungsi sebagai supervisor dalam melaksanakan supervisi hendaknya bertumpu pada prinsip supervisi. Prinsipprinsip dapat disebutkan sebagai berikut: ${ }^{14}$

a. Prinsip ilmiah yang mencakup unsur-unsur sebagai berikut:

1) Sistematis, yaitu dilaksanakan secara teratur, berencana dan kontinu.

2) Objektif artinya data yang didapat berdasarkan pada observasi nyata, bukan tafsiran pribadi.

3) Menggunakan alat/ instrument seperti angket, observasi, dan percakapan pribadi yang dapat memberikan informasi sebagai umpan balik untuk mengadakan penilaian terhadap proses belajar mengajar.

b. Prinsip demokratis Servis dan bantuan yang diberikan kepada guru berdasarkan hubungan kemanusiaan yang akrab. Demokratis mengandung makna menjunjung tinggi harga diri dan martabat guru, bukan berdasarkan atasan dan bawahan, tapi berdasarkan rasa kejawatan.

c. Prinsip kerjasama Seluruh staff sekolah dapat bekerja sama, mengembangkan usaha bersama dalam menciptakan situasi belajar mengajar yang lebih baik. Sharing of idea, sharing of experience, memberi support (mendorong), menstimulasi guru, sehingga mereka merasa tumbuh bersama.

d. Prinsip konstruktif dan kreatif Membina inisiatif guru serta mendorongnya untuk aktif menciptakan suasana dimana tiap orang merasa aman dan dapat mengembangkan potensinya. Prinsip ini menekankan bahwa kegiatan supervisi dilaksanakan untuk membangun dan mengembangkan potensi kreatif para guru. Supervisi diharapkan dilaksanakan dalam suasana yang menyenangkan, bukan menakut-nakuti. Dengan begitu para guru lebih termotivasi untuk mengembangkan potensi mereka.

Kompetensi supervisi ini sangat strategis bagi seorang kepala madrasah khususnya dalam memahami apa tugas dan fungsi kepala madrasah sebagai pemimpin. Kepala madrasahharus mampu menilai sub-sub kompetensinya yang mencakup: (a) merencanakan program supervisi akademik dalam rangka peningkatan profesio-nalisme guru; (b) melaksanakan supervisi akademik terhadap guru dengan menggunakan pendekatan dan teknik supervisi yang tepat; (c) menindaklan-juti hasil supervisi akademik terhadap guru dalam rangka

\footnotetext{
${ }_{11}$ Mukhtar dan Iskandar, Orientasi Baru Supervisi Pendidikan, (Jakarta: Gaung Persada Press, 2009), 41

12 Ngalim Purwanto, Administrasi dan Supervisi Pendidikan, (Bandung: PT Remaja Rosadakarya, 2005), 76

13 Piet A. Sahertian, Konsep Dasar dan Tekhnik Supervisi Pendidikan dalam Rangka Pengembangan Sumber Daya Manusia, (Jakarta: PT Rineka Cipta, 2000), 17.

14 Sahertian, Piet A, Konsep Dasar dan Tekhnik Supervisi Pendidikan dalam Rangka Pengembangan Sumber Daya Manusia. (Jakarta: PT Rineka Cipta, 2000).20
} 
peningkatan profe-sionalisme guru, di antaranya adalah bahwa tugas dan fungsi dari supervisi ini adalah untuk memberdayakan sumber daya sekolah termasuk guru. ${ }^{15}$

\section{Kompetensi Sosial Kepala Madrasah}

Kompetensi adalah seperangkat pengetahuan, keterampilan, dan perilaku, yang harus dimiliki, dihayati dan dikuasai oleh guru atau dosen dalam melaksanakan tugas keprofesionalan. ${ }^{16}$ Kompetensi sosial adalah kemampuan kepala madrasah sebagai bagian dari masyarakat untuk berkomunikasi dan bergaul secara efektif dengan peserta didik, sesama pendidik, tenaga kependidikan, orang tua atau wali peserta didik, dan masyarakat sekitar. ${ }^{17}$

Kompetensi ini pada dasarnya cukup sulit jika harus dikaitkan dengan aktivitas sosial yang dilakukan madrasah secara penuh, jika hal itu dilakukan dalam rangka keterkaitannya dengan program madrasah. Dalam rangka aktifitas sosial madrasah dapat bekerja sama dengan pihak lain untuk kepentingan madrasah, berpartisipasi dalam kegiatan sosial kemasyarakatan dan memiliki kepekaan sosial terhadap orang atau kelompok lain disekitar lingkungan madrasah.

Kompetensi kepala sekolah yang berhubungan dengan kemampuan untuk mengelola hubungan sekolah dengan masyarakat bisa diwujudkan melalui kemampuannya dalam hal: (1) memfasilitasi dan memberdayakan komite sekolah sebagai perwujudan pelibatan masyarakat terhadap pengembangan sekolah; (2) mencari dan mengelola dukungan dari masyarakat dalam hal pendanaan, pemikiran, moral, dan tenaga bagi pengembangan madrasah; (3) menyusun rencana dan program pelibatan orang tua siswa dan masyarakat; (4) mempromosikan madrasah kepada masyarakat; (5) membina kerjasama dengan pemerintah dan lembaga-lembaga masyarakat; dan (6) membina hubungan yang harmonis dengan orangtua siswa.

Kompetensi sosial ini kadang juga seriang berhubungan dengan tuntutan kepala madrasah dalam hal mengembangkan budaya madrasah secara adaptif, lebih baik, dan maju. Sub kompetensi ini bisa diwujudkan me-lalui kemampuannya untuk hal-hal berikut: (1) Menerapkan dan mengembangkan nilai-nilai kehidupan sekolah yang demokratis; (2) Membentuk budaya kerjasama (school corporate culture) yang kuat; (3) Menumbuhkan budaya profesionalisme warga sekolah; (4) Menciptakan iklim madrasah yang akademis; dan (5) Menumbuhkembangkan keragaman budaya dalam kehidupan madrasah ${ }^{18}$.

\section{Profesionalisme Kepala Madrasah}

15 Dirjen Peningkatan Mutu Tenaga Pendidik dan Tenaga Kependidikan, Penilaian Kinerja Kepala Sekolah, (Depdiknas, 2008), 20.

16 UU Nomor 14 Tahun 2005 tentang Guru dan Dosen.

17 Standar Nasional Pendidikan, penjelasan Pasal 28 ayat 3 butir d

18 Dirjen Peningkatan Mutu Tenaga Pendidik dan Tenaga Kependidikan, Penilaian Kinerja Kepala

Sekolah, (Depdiknas, 2008), 23 
Menjadi Kepala Madrasah professional harus memelihara budaya sekolah dengan sistem social yang ada dalam warga madrasah dalam konteks social budaya pendidikan di masyarakat. Kepala sekolah professional adalah kepala sekolah yang memegang teguh nilai dan etika serta budaya profesi sesuai dengan konteks social budaya pendidikan di masyarakat. Seorang pemimpin professional lembaga pendidikan madrasah dapat dilihat dari atribut yang melekat pada dirinya. Seorang pemimpin professional adalah pemimpin yang dapat dipercaya, dan orang-orang yang ada disekelilingnya akan tumbuh dan kemudian menghormatinya. Hal ini dikarenakan ia memiliki atribut sebagai berikut: ia adalah orang yang loyal kepada lembaga yang dipimpinnya, menunjukkan kepedulian kepada orang lain. Ia juga adalah seorang yang memiliki watak yang terpuji seperti jujur, cakap, tulus, pegang janji, sesuai antara perkataan dan perbuatan, berani, lurus, dan kreatif.

Seorang pemimpin professional adalah seorang yang memiliki pengetahuan yang luas. Ia adalah orang yang mengetahui dengan baik pegawainya, ia piawai berkomunikasi verbal dan nonverbal, dan ia mengenali benar situasi lingkungan tempat kerjanya. Ia memahami benar siapa dirinya, dan apa kelebihan dan kekurangan dari watak yang dimilikinya. Ia juga menyadari akan pengetahuan dan keterampilan yang dimilikinya. Sebagai seorang pemimpin, tentu saja ia telah mempelajari dengan mendalam kodrat manusia seperti kebutuhan manusia, emosi, dan bagaimana orang menyikapi stress. Disamping itu, seorang pemimpin professional adalah seorang yang mengetahui pekerjaan yang menjadi tanggungjawabnya. Ia adalah seorang yang cakap dan dapat melatih orang lain dalam menyelesaikan tugas-tugasnya. Dan yang tak kalah pentingnya adalah ia mengenal organisasi. Ia tahu kemana harus berkonsultasi dan meminta bantuan, ia mengenal iklim dan budaya kerja dan siapa-siapa pemimpin yang tidak resmi.

Seorang kepala madrasah professional adalah seorang yang mampu memberikan arah. Ia adalah seorang yang menetapkan tujuan yang akan dicapai, memberikan solusi terhadap setiap permasalahan, membuat berbagai keputusan dan perecanaan. Ia adalah seorang yang hebat dalam pengimplementasian konsep. Ia aktif berkomunikasi, berkoordinasi, mensupervisi dan mengadakan evaluasi. Dan yang terpenting adalah ia memotivasi. Ia membangun moral dan semangat kebersamaan dalam lembaga pendidikan madrasah, mengajarkan, melatih, dan memberi petuah. Kapala madrasah professional memang sangat menjanjikan, semua itu akan terwujud bila seorang kepala madrasah memiliki integritas untuk membaga pendidikan madrasah menjadi lembaga yang unggul dan berkualitas.

\section{Penutup}

Berdasarkan pembahasan di atas idealnya pemimpin madrasah; baik madrasah formal maupun non formal (diniyah) dalam mengelola madrasah harus memiliki kompetensi kepemimpinan dan menggunakan manajemen yang jelas dan berorientasi pada pengebangan mutu. Manajemen ini tentunya dapat dilaksanakan apabila kepala madrasah sebagai pemimpin harus profesional. 
Pemimpin profesional madrasah yang dimaksud yaitu kepala madrasah harus meaksanakan tugas pokok kepala madrasah yang mencakup tiga bidang, yaitu: tugas manajerial, supervisi dan kewirausahaan. Selain itu harus memiliki enam kompetensi, yaitu: Kompetensi Kepribadian, Kompetensi Manajemerial, Kompetensi Kewirausahaan, Kompetensi Supervisi, Kompetensi Sosial, dan kompeensi Profesional.Semuga uraian singkat ini dapat bermanfaat untuk kita semua.

\section{Daftar Pustaka}

Asmara, U. Husna, Pengantar Kepemimpinan Pendidikan (Bogor: Ghalia Indonesia, 1985).

Bambang Wijanarko, Konsep Kewirausahaan Bagi Kepala Sekolah, (http://www.vedcmalang.com, 2015).

Dirjen Pendidikan Islam, Penilaian Kinerja Kepala Sekolah, (Kemenag RI, 2015).

Fatah, Nanang, Landasan Manajemen Pendidikan (Bandung: Remaja Rosda Karya, 1999).

Mukhtar dan Iskandar, Orientasi Baru Supervisi Pendidikan, (Jakarta: Gaung Persada Press, 2009).

Muhaimin, Wacana Pengembangan Pendidikan Islam (Yogyakarta: Pusat Studi Agama, Politik dan Masyarakat (PSAPM) bekerjasama dengan Pustaka Pelajar, 2003).

Purwanto, Ngalim, Administrasi dan Supervisi Pendidikan, (Bandung: PT Remaja Rosadakarya, 2005).

Sahertian, Piet A., Konsep Dasar dan Tekhnik Supervisi Pendidikan dalam Rangka Pengembangan Sumber Daya Manusia, (Jakarta: PT Rineka Cipta, 2000).

Standar Nasional Pendidikan, penjelasan Pasal 28 ayat 3 butir d Syafaruddin, Manajemen Mutu Terpadu dalam Pendidikan, Konsep, Strategi, dan Aplikasi (Jakarta: PT. Gramedia Widiasarana Indonesia, 2002).

Sagala, Syaiful, Administrasi Pendidikan Kontemporer (Bandung: Alfabeta, 2005).

UU Nomor 14 Tahun 2005 tentang Guru dan Dosen. 